\title{
Introduction and spread of non-native parasites with Silurus glanis L. (Teleostei: Siluridae) in UK fisheries
}

\author{
A.J. Reading ${ }^{1 *}$, J.R. Britton ${ }^{2}$, G.D. Davies ${ }^{1}$, A.P. Shinn ${ }^{3}$ \\ and C.F. Williams ${ }^{1}$ \\ ${ }^{1}$ Environment Agency, Brampton, Cambridgeshire PE28 4NE, UK: \\ ${ }^{2}$ Centre for Conservation Ecology and Environmental Science, School of \\ Applied Sciences, Bournemouth University, Poole BH12 5BB, UK: \\ ${ }^{3}$ Institute of Aquaculture, University of Stirling, Stirling FK9 4LA, UK
}

(Accepted 18 October 2011)

\begin{abstract}
Despite growing concern of the ecological risks posed by the European catfish Siluris glanis L. in freshwater fisheries, little information exists on the parasite fauna of this silurid catfish in Britain. Parasitological examinations of released S. glanis from four still-water fisheries in England revealed the presence of Thaparocleidus vistulensis (Siwak, 1932) and Ergasilus sieboldi (Nordmann, 1832), both non-native parasites, the latter known to be an important fish pathogen. This represents the first record of T. vistulensis from British freshwater fish. The human-assisted movement of $S$. glanis between UK recreational still-water fisheries provides a clear avenue for the introduction and spread of non-native parasites.
\end{abstract}

\section{Introduction}

An inherent and persistent risk associated with fish introductions is the transmission of their parasitic fauna to native host fishes (Kennedy, 1994; Kirk, 2003). These naïve hosts may be highly susceptible to infection where there has been a lack of host-parasite co-evolution, which may result in low natural immunity, altered disease dynamics and poor anti-parasite behaviour (Taraschewski, 2006; Kelly et al., 2009). Transmission of non-native parasites to new geographical localities has already resulted in serious and irreversible effects in some species, such as the detrimental effect of Anguillicoloides crassus (Kuwahara, Niimi et Itagaki, 1974) on the European eel Anguilla anguilla L. (Székely et al., 2009). The global spread of parasites with invading hosts is therefore a major cause of disease emergence and holds important implications for native aquatic environments (Gozlan et al., 2005, 2009; Perkins et al., 2008; Peeler et al., 2011).

\footnotetext{
*E-mail: amy.reading@environment-agency.gov.uk
}

In England and Wales the European catfish Silurus glanis L. has been widely introduced for enhancing the performance of recreational lake fisheries (Britton et al., 2010). Many of these introductions have been completed outside of relevant regulatory frameworks and so have not been subjected to risk assessment processes prior to their release (Hickley \& Chare, 2004; Copp et al., 2005, 2009). In order to better understand the ecological risks associated with this species, research has been conducted to assess the invasiveness of this fish in the UK. Most of this work has focused on colonization potential under current and future climatic conditions (Britton et al., 2007, 2010; Copp et al., 2009). However, according to Copp et al. (2009), virtually all aspects of the environmental biology of $S$. glanis require further study. This includes disease risk, as to date little attention has been given to the parasite fauna of this fish in Britain, despite awareness that it may serve as host for a wide range of parasite species (Copp et al., 2009). In an effort to address this knowledge gap, the present study describes the results of parasitological investigations of S. glanis from freshwater fisheries. 


\section{Materials and methods}

Between 2009 and 2011, five specimens of S. glanis (50$170 \mathrm{~cm}$ ) were examined from four different still-water fisheries in England. These fish were made available as part of Environment Agency investigations into the colonization potential and invasion biology of S. glanis in inland waters in England and Wales. These sites were located in Staffordshire, Hampshire, Kent and Essex (precise locations withheld for confidentiality).

All fish were captured by means of seine netting and transported alive to holding facilities at the Environment Agency, Brampton. Fish were killed by lethal anaesthesia (benzocaine solution $5 \% \mathrm{w} / \mathrm{v}$ ) and examined for external and internal parasites, using low- and high-power light microscopy. The identity, site of attachment and approximate intensity of any parasites that were encountered were recorded.

\section{Results and discussion}

The ancyrocephalid monogenean parasite, Thaparocleidus vistulensis (Siwak, 1932) was recorded on the gills of all five fish (intensity range 1-35 per gill arch). Identification was confirmed from examination of the copulatory complex (fig. 1a) and the haptoral sclerites (fig. 1b and c).

Other parasite findings included light infections of Camallanus lacustris (Zoega, 1776) in the intestinal tract (mean intensity, 1), Argulus foliaceus (L.) on the skin (mean intensity, 1), Diplostomum spp. in the eye (intensity range 1-5), Trypanosoma spp. in the kidney and Ergasilus sieboldi (Nordmann, 1832) on the gill lamellae (intensity range 1-10 per gill arch).

These studies provide the first record of T. vistulensis in the UK. This parasite is a specialist of siluriform fishes. Voucher specimens of $T$. vistulensis have been deposited in the parasitic worm collection of the Natural History Museum, London (NHMUK 2011.10.27.1-3). Ergasilus sieboldi is also a non-native parasite, but may infect a wide range of fish species (Fryer, 1969).

Thaparocleidus spp. have been recorded from much of Asia and Europe (Lim et al., 2001; Moravec, 2001; Galli et al., 2003; Copp et al., 2009). Specific records for $T$. vistulensis include Italy, the Czech Republic, the Slovak Republic and Poland (Siwak, 1932; Moravec, 2001; Paladini et al., 2008), although these are likely to reflect detection effort rather than the true extent of distribution. Limited information exists on the pathogenicity of T. vistulensis and the pathology of this parasite has not been described. Blanc (1997) listed a number of ancyrocephalid Monogenea in a table of introduced fish pathogens. However, the pathogenic importance of these species was not detailed.

Despite the examination of only a small number of fish, the recording of $T$. vistulensis confirms the potential for introduced fish to concomitantly introduce their parasitic fauna into areas outside of their natural range. This finding closely follows the detection of the ancyrocephalid
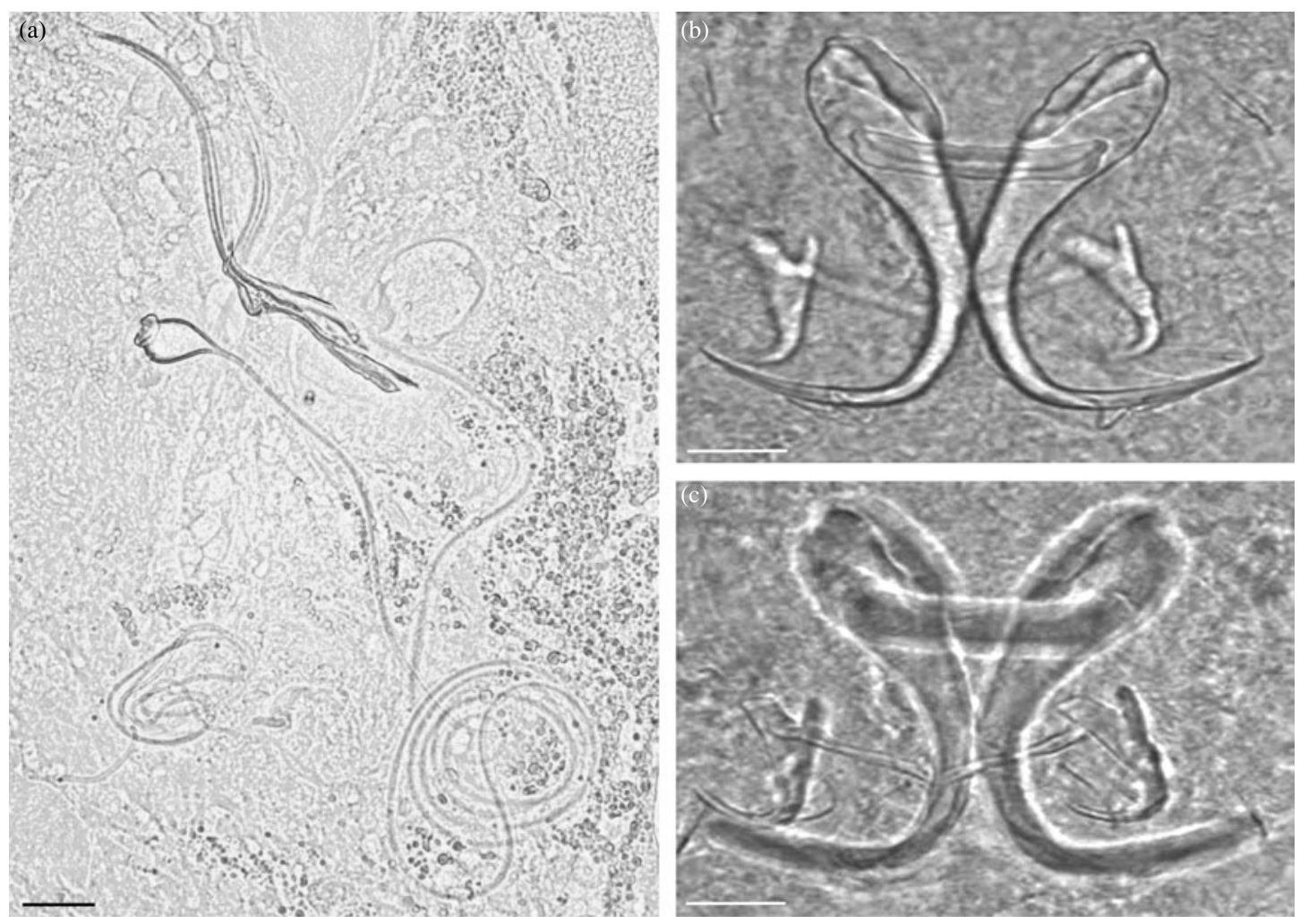

Fig. 1. Copulatory complex (a) and haptoral sclerites (b, c) of Thaparocleidus vistulensis (Siwak, 1932). Scale bar $=20 \mu \mathrm{m}$. 
monogenean Onchocleidus dispar (Müller, 1936) in pumpkinseed Lepomis gibbosus (L.) introduced into the UK (Hockley et al., 2011). Andrews \& Chubb (1984) recorded Proteocephalus osculatus (Goeze, 1782), a common parasite of catfish in Russia, from S. glanis imported to a fish farm in Yorkshire, England. Although the fate of these fish was not detailed, it can be assumed that parasite colonization was prevented as these fish underwent antihelminthic treatment.

Many non-native monogeneans have been recorded in Europe following fish translocations (Johnson \& Jensen, 1991; Moravec, 2001; Galli et al., 2003). Although the potential for disease surrounds any parasite introduction (Kennedy, 1994), the risk posed by these monogeneans may be limited due to their purported strict host specificity. Thaparocleidus vistulensis is restricted to freshwater siluriforms that are naturally absent from the UK fish fauna (Lim et al., 2001; Davies et al., 2004; Paladini et al., 2008).

However, the simultaneous detection of E. sieboldi in the examined fish highlights a potential disease risk to native host species. The high reproductive rate, direct lifecycle and low host specificity of many ergasilid parasites have led to their rapid colonization and spread. Ergasilus sieboldi has a predilection for large fish and has been the cause of mortality in a range of fish species in still-water fisheries (Alston \& Lewis, 1994; Tildesley, 2008). The spread of this parasite with wels catfish represents an additional disease risk, as fishery managers and anglers have a propensity to stock large specimens of $S$. glanis for enhancing lake fisheries (Hickley \& Chare, 2004; Britton et al., 2007). These human-driven fish movements are the result of the commoditization of such valuable fish within the UK recreational fishery sector (Hickley \& Chare, 2004) and provide a dispersal pathway for the introduction and spread of fish pathogens.

The translocation of parasites with the trade in fish represents a considerable threat to aquatic biodiversity and fishery development (Copp et al., 2005; Gozlan et al., 2006). Examples of disease outbreaks following the introduction of non-native parasites, including a number of monogeneans, are well documented (Johnson \& Jensen, 1991; Bauer et al., 2002; Matsche et al., 2010). Many biotic and abiotic factors influence the colonization, establishment and pathogenicity of introduced parasites (Kennedy, 1994). However, the illegal release of alien fish species into the wild (BBC, 2008), and increasing demand for large and unusual species like catfish and sturgeon, Acipenser spp., as sport fish (Hickley \& Chare, 2004), provide clear avenues for disease transfer. The introduction of Bothriocephalus acheilognathi Yamaguti, 1934 with imported fathead minnow Pimephales promelas Rafinesque, 1820 (C. Williams, pers. obs.) and the accidental discovery of the Rosette agent Sphaerothecum destruens Arkush, Mendoza, Adkison et Hedrick, 2003, in the highly invasive topmouth gudgeon Pseudorasbora parva (Temminck et Schlegel, 1846) (Gozlan et al., 2009), further illustrate these dangers. Current risk assessment frameworks may not be sufficient to prevent new parasite introductions from occurring, emphasizing the need for continued disease monitoring of high-risk fish movements and strengthening regulatory efforts to protect freshwater fisheries.

\section{Acknowledgements}

The authors would like to thank Environment Agency colleagues for the collection of catfish samples and assistance with dissections, as well as Giuseppe Paladini (University of Stirling) for confirming the identification of T. vistulensis. The opinions provided in this paper are those of the authors and not their parent organizations.

\section{References}

Alston, S. \& Lewis, J.W. (1994) The ergasilid parasites (Copepoda: Poecilostomatoida) of British freshwater fish. pp. 171-189 in Pike, A.W. \& Lewis, J.W. (Eds) Parasitic diseases of fish. Dyfed, UK, Samara.

Andrews, C. \& Chubb, J.C. (1984) Helminth parasites from Yorkshire fishes. Bulletin of the European Association of Fish Pathologists 4, 22-23.

Bauer, O.N., Pugachev, O.N. \& Voronin, V.N. (2002) Study of parasites and diseases of sturgeons in Russia: a review. Journal of Applied Ichthyology 18, 420-429.

BBC (2008) Angler lands tropical snakehead. Available at http://news.bbc.co.uk/1/hi/england/lincolnshire/ 7252908.stm (accessed 15 November 2011).

Blanc, G. (1997) Introduction of pathogens in European aquatic ecosystems: attempt of evaluation and realities. Bulletin Français de la Pêche et de la Pisciculture 344-345, 37-56.

Britton, J.R., Davies, G.D., Brazier, M. \& Pinder, A.C. (2007) A case study on the population ecology of a topmouth gudgeon Pseudorasbora parva population in the UK and the implications for native fish communities. Aquatic Conservation: Marine \& Freshwater Ecosystems 17, 749-759.

Britton, J.R., Cucherousset, J., Davies, G.D., Godard, M.J. \& Copp, G.H. (2010) Non-native fishes and climate change: predicting species responses to warming temperatures in a temperate region. Freshwater Biology 55, 1130-1141.

Copp, G.H., Garthwaite, R. \& Gozlan, R.E. (2005) Risk identification and assessment of non-native freshwater fishes: Concepts and perspectives on protocols for the UK. UK Science Series Technical Report, 129. 32 pp. Lowestoft, Cefas.

Copp, G.H., Britton, J.R., Cucherousset, J., GarcíaBerthou, E., Kirk, R., Peeler, E.J. \& Stakènas, S. (2009) Voracious invader or benign feline? A review of the environmental biology of European catfish Silurus glanis in its native and introduced range. Fish $\mathcal{E}$ Fisheries 10, 252-292.

Davies, C., Shelley, J., Harding, P., McLean, I., Gardiner, R. \& Peirson, G. (2004) Freshwater fishes in Britain: The species and their distribution. 176 pp. Colchester, Harley Books.

Fryer, G. (1969) The parasitic copepod Ergasilus sieboldi Nordmann, new to Britain. Naturalist 909, 49-51.

Galli, P., Stefani, F., Benzoni, F., Crosa, G. \& Zullini, A. (2003) New records of alien monogeneans from Lepomis gibbosus and Silurus glanis in Italy. Parassitologia 45, 147-149.

Gozlan, R.E., St-Hilaire, S., Feist, S.W., Martin, P. \& Kent, M.L. (2005) Disease threat to European fish. Nature 435, 1046. 
Gozlan, R.E., Peeler, E.J., Longshaw, M., St-Hilaire, S. \& Feist, S.W. (2006) Effect of microbial pathogens on the diversity of aquatic populations, notably in Europe. Microbes and Infection 8, 1358-1364.

Gozlan, R.E., Whipps, C.M., Andreou, D. \& Arkush, K.D. (2009) Identification of a rosette-like agent as Sphaerothecum destruens, a multi-host fish pathogen. International Journal for Parasitology 39, 1055-1058.

Hickley, P. \& Chare, S. (2004) Fisheries for non-native species in England and Wales. Angling or the environment? Fisheries Management and Ecology 11, 203-212.

Hockley, F.A., Williams, C.F., Reading, A.J., Taylor, N.G.H. \& Cable, J. (2011) Parasite fauna of introduced pumpkinseed fish Lepomis gibbosus: first British record of Onchocleidus dispar (Monogenea). Diseases of Aquatic Organisms 97, 65-73.

Johnson, B.O. \& Jensen, A.J. (1991) The Gyrodactylus story in Norway. Aquaculture 98, 289-302.

Kelly, D.W., Paterson, R.A., Townsend, C.R., Poulin, R. \& Tompkins, M. (2009) Has the introduction of brown trout altered disease patterns in native New Zealand fish? Freshwater Biology 54, 1805-1818.

Kennedy, C.R. (1994) The ecology of introductions. pp. 189-208 in Pike, A.W. \& Lewis, J.W. (Eds) Parasitic diseases of fish. Dyfed, UK, Samara Publishing.

Kirk, R.S. (2003) The impact of Anguillicola crassus on European eels. Fisheries Management and Ecology 10, 385-394.

Lim, L.H.S., Timofeeva, T.A. \& Gibson, D.I. (2001) Dactylogyridean monogeneans of the siluriform fishes of the Old World. Systematic Parasitology 50, 159-197.

Matsche, M.A., Flowers, J.R., Markin, E.L. \& Stence, C.P. (2010) Observations and treatment of Nitzschia sturionis on Atlantic sturgeon from Chesapeake Bay. Journal of Aquatic Animal Health 22, 174-181.
Moravec, F. (2001) Checklist of the metazoan parasites of fishes of the Czech Republic and Slovak Republic (1873-2000). 168 pp. Praha, Academia.

Paladini, G., Gustinelli, A., Fioravanti, M.L., Minardi, D. \& Prearo, M. (2008) Redescription of Thaparocleidus vistulensis (Monogenea: Ancylodiscoididae) from Wels catfish (Silurus glanis L.) from Po river and taxonomic status of the genus. Ittiopatologia 5, 129-138 (in Italian).

Peeler, E.J., Oidtmann, B.C., Midtlyng, P.J., Miossec, L. \& Gozlan, R.E. (2011) Non-native aquatic animal introductions have driven disease emergence in Europe. Biological Invasions 13, 1291-1303.

Perkins, S.E., Altizer, S., Bjornstad, O., Burdon, J.J., Clay, K., Gómez-Aparicio, L., Jeschke, M., Johnson, P.T.J., Lafferty, K.D., Malmstrom, C.M., Mertin, P., Power, A., Strayer, D.L., Thrall, P.H. \& Uriarte, M. (2008) Invasion biology and parasitic infections. pp. 347-367 in Ostfeld, R.S. \& Keesing, F. (Eds) Infectious disease ecology - effects of ecosystems on disease and of disease on ecosystems. Princeton, Princeton University Press.

Siwak, J. (1932) Ancyrocephalus vistulensis sp. n., un nouveau trématode, parasite du silure (Silurus glanis L.). Bulletin de l'Academy Polonica, Sciences et Lettres. Sciences Naturelle, Series B 11, 669-679.

Székely, C., Palstra, A., Molnár, K. \& Van den Thillart, G. (2009) Impact of the swim-bladder parasite on the health and performance of European eels. pp. 201-228 in Van den Thillart, G., Dufour, S. \& Rankin, C. (Eds) Spawning migration of the European eel. Heidelberg, Springer.

Taraschewski, H. (2006) Hosts and parasites as aliens. Journal of Helminthology 80, 99-128.

Tildesley, A.S. (2008) Investigations into Ergasilus sieboldi (Nordmann 1832) (Copepoda: Poecilostomatoida), in a large reservoir rainbow trout fishery in the UK. Unpublished PhD thesis, University of Stirling, UK. 